\title{
Effects of ethnic changes on house prices: Sydney cases
}

\author{
Xin Janet Ge \\ University of Technology Sydney
}

\begin{abstract}
Australia is a multicultural country with diversified ethnicities. The median price of established houses (unstratified) in Sydney has reached a new record high of \$910,000 in December 2015, increasing around 58.2 per cent from March 2011 (ABS, 2015a). However, the prices of some suburbs have increased more than prices of others. This research investigates the factors that contribute to the changes of house prices including ethnic factors. Six suburbs that represent ethnic majorities originally including White, Indians and Chinese are selected as pilot studies. Hedonic regression analysis is applied for the analysis based on 2001, 2006 and 2011 census data. It is found that the main drivers of house prices are the dwellings' physical characteristics and the level of household income. However, the impact of changes in ethnicity on prices is not significant. This paper discusses the ethnic changes in the demographic composition of Sydney's suburbs. The paper will first investigate the ethnic changes in the suburbs of Sydney and then compare the main characteristics amongst the studied suburbs. The relationship between changes of ethnic profile and dwelling prices will be analysed.
\end{abstract}

Keywords: Ethnic diversity, residential segregation, immigrants, dwelling prices, hedonic approach, Sydney

\section{INTRODUCTION}

This paper conducts a pilot study investigating the factors that contribute to the changes of house prices including ethnic profiles. Lately, dwelling prices in Sydney have been soaring rapidly. The median price of established houses (unstratified) reached \$910,000 in December 2015 (ABS, 2015a). However, the prices of some suburbs have increased more than prices of others. There are some public figures blaming new migrants for pushing up the prices. Australia is a multicultural country with diversified ethnicity and immigration consists of around 55 per cent of Australia's population growth. There were around 200,000 net overseas migrants per year for the period of 2009-10 to 2014-15 in Australia. Around 90 per cent of them settled in the main cities of NSW (31 per cent), VIC (27 per cent), QLD (17 per cent) and Western Australia (17 per cent).

In the year to 30 June 2016, Australia's population grew by 337,800 people (1.4 per cent) reaching 24.127 million. Net overseas migration accounted for 54 per cent of the total population growth (ABS, 2015b). About 28.2 per cent (6.7 million) of Australia's estimated resident population were born overseas (ABS, 2015b). People born in the United Kingdom was the largest group of overseas-born residents, accounting for $5.1 \%$ of Australia's total population, followed by New Zealand (2.6\%), China (2.0\%), India (1.8\%), and the Philippines and Vietnam (both 1.0\%) for the same period.

In Sydney, the majority are Caucasians (Australian, English, New Zealander, Italian, etc.). They live mostly along the coastline (e.g., Northern Beaches, the Eastern Suburbs, the Sutherland Shire) and far-western and Southwestern Sydney, as well as rural areas, which are relatively far away from city centre and transports. People of East and South East Asian origins are found to settle near train lines, in particular the Northern Line. A possible reason given is that Asians are more accustomed to highrise living and reliance on public transport (ABS, 2011). In recent years, numerous high-rise buildings were developed at places such as Rhodes, where Asians may constitute the majority. The spread of people of sub-continental origin (Indian or Sinhalese origin) in Sydney appears restricted to Parramatta and Harris Park. The topic of this paper is how the changes in ethnicity affect housing values. 
In order to answer this question, six suburbs with an ethnic majority originally from India, China or Australia was used as a pilot study. Hedonic regression analysis was applied for the analysis based on census 2001, 2006 and 2011 data. This paper discusses the ethnic changes in the demographic composition of selected Sydney's suburbs. The paper will start from investigating the shifts of ethnic changes in the suburbs of Sydney and then compare the main characteristics amongst the studied suburbs. The relationship between changes of ethnic profile and dwelling prices will be analysed.

\section{THE SUBURB ETHNIC STRUCTURES}

Immigration not only contributes to economic advance of a country but also changes its ethnic structure (Li, 2014). In Australia, most immigrants have settled in major cities with substantial economic growth, which in Australia would include Sydney and Melbourne (Bourassa, 1994). For the purpose of this study, for each ethnic group, two suburbs in Sydney were chosen to conduct the analysis of relationship between ethnicity and housing prices: Leichhardt and Manly for Caucasians, Epping and Rhodes for East Asians, and Parramatta and Westmead for the Sub-continental. Birthplace of origin is used to distinguish the ethnic groups.

Table 1 depicts the ethnic structure of the six suburbs. In Parramatta and Westmead, the fact that population born overseas exceeded population born in Australia reflects cultural diversity in both suburbs. Parramatta is 23 kilometres west from the Sydney CBD. It is a major business and commercial centre, and the second largest CBD in the State of New South Wales with a population of 19,745 (ABS census, 2011) and many high-density commercial and residential developments. It has the highest unemployment rates of the studied suburbs at around 8 to 9 per cent, and the lowest weekly household income among the studied suburbs.

In Parramatta, the proportion of population born in India increased rapidly from 6 per cent in 2001 to 14.1 in 2006 and 21.5 in 2011. The India-born population in Westmead increased from 5.7 per cent of the suburb population to 16.3 per cent and 29.7 per cent in 2006 and 2011 respectively. Population born in mainland China in the two suburbs also increased. However, the rate of growth was not very high, with proportions of 9.4, 12.8 and 14.7 per cent in Parramatta and around 5 per cent in Westmead for each of the three censuses. During the same period, people born in the UK, New Zealand and Italy appeared to move out from the two suburbs gradually.

In the suburbs of Epping and Rhodes, the proportion of the population born in Mainland China is high and shows a growing tendency, with 4.5, 8.2 and 11.7 per cent increase respectively in 2001, 2006 and 2011 in Epping. Rhodes has the smallest population among the studied suburbs with only around 5,500 people. The built environment of Rhodes has changed and many apartments have been built in the area recent years. Many Chinese are attracted to the suburb. The possible reasons include 1) the place is relatively close to $\mathrm{CBD}$ with good rail transportation; 2) a shopping centre with restaurants; and 3) green environment with water view. An obvious increase appeared from 2006 to 2011, when the proportion of people born in China rose from 4.7 per cent to 25.4 per cent.

Manly which tends to be favoured by the White is a beach-side suburb located 17 kilometres north of Sydney. The median house price in Manly is around \$2.3 million in 2016, which is higher than Sydney's median house price of $\$ 910,000$ (RPData, 2016). Similarly, the average rental price per week is $\$ 1,037$, much higher than Sydney average of $\$ 485$ in February 2016. Leichhardt is a suburb in the Inner West of Sydney, located 5 kilometres west of the Sydney CBD. This suburb has a mix of residential and commercial developments and is best known as Sydney's "Little Italy". The statistics showed that the birthplaces of around 15 to 19 per cent of population in Manly, and around 13 to 14 per cent of population in Leichhardt were born in the UK, New Zealand or Italy. In particular, UK people are attracted to Manly, and made up 10.7, 12.5 and 14.2 per cent of local population in 2001, 2006 and 2011 respectively. 
Table 1: Suburb Ethnic Profile

\begin{tabular}{|c|c|c|c|c|c|c|c|c|c|c|c|c|c|c|c|c|c|c|}
\hline \multirow{2}{*}{ Items } & \multicolumn{3}{|c|}{ Parramatta } & \multicolumn{3}{|c|}{ Westmead } & \multicolumn{3}{|c|}{ Epping } & \multicolumn{3}{|c|}{ Rhodes } & \multicolumn{3}{|c|}{ Manly } & \multicolumn{3}{|c|}{ Leichhardt } \\
\hline & 2001 & 2006 & 2011 & 2001 & 2006 & 2011 & 2001 & 2006 & 2011 & 2001 & 2006 & 2011 & 2001 & 2006 & 2011 & 2001 & 2006 & 2011 \\
\hline Transaction (House NO) & 59 & 38 & 62 & 25 & 40 & 37 & 147 & 129 & 149 & 6 & 5 & 11 & 42 & 37 & 43 & 98 & 127 & 53 \\
\hline Median ('000) & $\$ 370$ & $\$ 460$ & $\$ 542.5$ & $\$ 383$ & $\$ 499$ & $\$ 615$ & $\$ 520$ & $\$ 705$ & $\$ 935$ & $\$ 408$ & $\$ 600$ & $\$ 1,030$ & $\$ 914.4$ & $\$ 1,300$ & $\$ 1,885$ & $\$ 451.5$ & $\$ 627$ & $\$ 820$ \\
\hline Transaction (Unit NO) & 393 & 217 & 770 & 85 & 126 & 319 & 105 & 80 & 220 & 3 & 84 & 604 & 199 & 188 & 363 & 37 & 83 & 81 \\
\hline Median ('000) & $\$ 230.0$ & $\$ 495.0$ & $\$ 425.0$ & $\$ 255.0$ & $\$ 302.5$ & $\$ 379.0$ & $\$ 329.0$ & $\$ 416.5$ & $\$ 580.5$ & $\$ 405.5$ & $\$ 504.9$ & $\$ 600.0$ & $\$ 465.0$ & $\$ 642.5$ & $\$ 695.0$ & $\$ 399.0$ & $\$ 408.8$ & $\$ 694.5$ \\
\hline Median household weekly income & $\$ 900$ & $\$ 1,022$ & $\$ 1,314$ & $\$ 900$ & $\$ 1,064$ & $\$ 1,475$ & $\$ 1,100$ & $\$ 1,432$ & $\$ 1,683$ & $\$ 1,100$ & $\$ 1,565$ & $\$ 1,617$ & $\$ 1,100$ & $\$ 1,591$ & $\$ 2,084$ & $\$ 1,100$ & $\$ 1,516$ & $\$ 1,924$ \\
\hline Median mortgage payment/month & $\$ 1,100$ & $\$ 1,571$ & $\$ 1,950$ & $\$ 1,100$ & $\$ 1,649$ & $\$ 2,000$ & $\$ 1,500$ & $\$ 1,950$ & $\$ 2,286$ & $\$ 1,500$ & $\$ 2,383$ & $\$ 2,600$ & $\$ 1,700$ & $\$ 2,300$ & $\$ 3,000$ & $\$ 1,500$ & $\$ 2,200$ & $\$ 2,817$ \\
\hline Median weekly rent & $\$ 225$ & $\$ 230$ & $\$ 350$ & $\$ 225$ & $\$ 230$ & $\$ 360$ & $\$ 550$ & $\$ 300$ & $\$ 420$ & $\$ 275$ & $\$ 375$ & $\$ 560$ & $\$ 325$ & $\$ 380$ & $\$ 530$ & $\$ 325$ & $\$ 340$ & $\$ 460$ \\
\hline Population & 18292 & 18447 & 19745 & 10210 & 9486 & 14171 & 18347 & 18969 & 20227 & 743 & 1671 & 5679 & 14922 & 13949 & 15072 & 12608 & 12249 & 13520 \\
\hline Birthplace in Australia & 6631 & 5991 & 5427 & 4542 & 3364 & 4271 & 10870 & 10174 & 10020 & 500 & 778 & 1349 & 7800 & 7207 & 7137 & 7995 & 7805 & 8791 \\
\hline Birthplace in Overseas & 9157 & 10633 & 14318 & 4512 & 5368 & 9030 & 6567 & 7840 & 9595 & 181 & 646 & 3711 & 4497 & 4806 & 5818 & 3744 & 3430 & 4002 \\
\hline Birth (India) & 1112 & 2603 & 4241 & 586 & 1543 & 4203 & 414 & 689 & 921 & 0 & 20 & 218 & 49 & 45 & 60 & 59 & 56 & 94 \\
\hline Birth (PR China) & 1711 & 2370 & 2909 & 411 & 557 & 814 & 821 & 1559 & 2360 & 25 & 79 & 1441 & 77 & 85 & 77 & 60 & 67 & 106 \\
\hline Birth (UK) & 392 & 309 & 235 & 256 & 171 & 197 & 681 & 597 & 560 & 36 & 61 & 125 & 1592 & 1750 & 2136 & 709 & 691 & 836 \\
\hline Birth (New Ze & 469 & 403 & 326 & 231 & 195 & 220 & 264 & 243 & 225 & 8 & 26 & 92 & 671 & 612 & 626 & 412 & 380 & 433 \\
\hline Birth (Italy) & 60 & 49 & 50 & 49 & 34 & 39 & 109 & 91 & 84 & 11 & 16 & 18 & 53 & 60 & 78 & 683 & 531 & 507 \\
\hline Australian citizen & 11716 & 11111 & 10546 & 7088 & 6190 & 8589 & 15140 & 15237 & 16179 & 620 & 1130 & 2514 & 9708 & 8963 & 10055 & 10467 & 10028 & 11275 \\
\hline Median age & 32 & 30 & 30 & 33 & 33 & 31 & 36 & 37 & 38 & 39 & 32 & 28 & 35 & 35 & 35 & 34 & 35 & 36 \\
\hline Fully owned & 1378 & 976 & 870 & 698 & 511 & 606 & 3328 & 2724 & 2819 & 115 & 115 & 287 & 1875 & 1562 & 1550 & 1597 & 1191 & 1243 \\
\hline Owned with mortgage & 930 & 1444 & 1685 & 372 & 688 & 1138 & 1235 & 1826 & 2084 & 56 & 192 & 627 & 740 & 978 & 1297 & 1308 & 1657 & 1907 \\
\hline Rented & 4018 & 4361 & 4389 & 1978 & 2007 & 3018 & 1685 & 1784 & 2044 & 69 & 270 & 1210 & 3020 & 2797 & 3285 & 2191 & 2046 & 2165 \\
\hline Separate house (persons) & 4148 & 3491 & 3023 & 2699 & 2722 & 2958 & 12999 & 13092 & 13414 & 504 & 475 & 538 & 2224 & 2586 & 2777 & 6217 & 5176 & 5712 \\
\hline Semi-detached (persons) & 1699 & 2038 & 1232 & 347 & 363 & 1597 & 1247 & 1363 & 1807 & 159 & 198 & 253 & 1601 & 1441 & 1774 & 3780 & 4177 & 4337 \\
\hline Flat, unit, apartment (persons) & 11153 & 11213 & 12916 & 4299 & 5329 & 8279 & 3733 & 3668 & 4315 & 13 & 723 & 4150 & 8874 & 7292 & 8513 & 1988 & 1750 & 2237 \\
\hline Total private dwellings (persons) & 17208 & 16919 & 17225 & 8269 & 8418 & 12851 & 18041 & 18184 & 19577 & 676 & 1396 & 5000 & 12994 & 11391 & 13132 & 12199 & 11180 & 12392 \\
\hline Separate house (dwellings) & 1444 & 1196 & 993 & 977 & 938 & 966 & 4300 & 4236 & 4447 & 168 & 160 & 198 & 793 & 940 & 985 & 2536 & 2109 & 2224 \\
\hline Semi-detached (dwellings) & 711 & 759 & 461 & 151 & 149 & 614 & 500 & 522 & 661 & 78 & 91 & 103 & 695 & 581 & 704 & 1732 & 1830 & 1880 \\
\hline Flat, unit, apartment (dwellings) & 5109 & 5008 & 5645 & 2155 & 2251 & 3319 & 1868 & 1711 & 1980 & 6 & 330 & 1838 & 5010 & 4004 & 4597 & 1178 & 1056 & 1293 \\
\hline Total private dwellings (dwellings) & 8003 & 7073 & 7701 & 3693 & 3338 & 5223 & 7118 & 6521 & 7517 & 263 & 581 & 2462 & 7747 & 5577 & 7536 & 5905 & 5035 & 5884 \\
\hline Other dwellings & 739 & 110 & 602 & 410 & 0 & 324 & 450 & 52 & 429 & 11 & 0 & 323 & 1249 & 52 & 1250 & 459 & 40 & 487 \\
\hline Unemployment( \%) & 9.5 & 8.1 & 8.2 & 8.8 & 8.3 & 7.5 & 4.6 & 4.3 & 6.1 & 4.9 & 6.3 & 7.8 & 4.6 & 3.3 & 3.7 & .4 .4 & 3.2 & 4.0 \\
\hline Average household size & 2.4 & 2.4 & 2.4 & 2.4 & 2.5 & 2.6 & 2.7 & 2.8 & 2.8 & 2.7 & 2.4 & 2.3 & 2 & 2.1 & 2.1 & 2.2 & 2.2 & 2.3 \\
\hline
\end{tabular}

(Source: ABS Census 2011)

With regards to the house prices, all studied suburbs showed similar trends (Refer to Figure 1). House prices in Rhodes soared strongly in 2013 with 41.3 per cent. The price continued to increase by 23 and 40.1 per cent in 2014 and 2015 respectively. The possible explanation was the inflow of capital from Mainland China. Epping is another area of soaring prices with 20.2, 32.2 and 16.7 per cent capital growth in 2013, 2014 and 2015 respectively. Epping has been popular among Chinese purchasers. The area is a transport hub accessible to the Northshore and Northern lines. The new northwest link is being developed to improve the accessibility to the northwest corridor. To accommodate the changes, lands around the train stations have been rezoned to medium and high densities. The expectation on future growth could be one of the reasons for the continuing price increase.

Parramatta, located west of Sydney, is the second largest business centre after Sydney CBD. The job opportunities attract population to the suburb thus raise the demand for housing. Constant house price growth since 2011 indicates a continuing trend, with 32.2 and 24.7 per cent increase respectively in 2014 and 2015. In Manly and Leichhardt, the median house capital growth was relatively steady. In 2014 and 2015 the increase reached 25.7 and 12.4 per cent in Manly; and 13.2 and 13 per cent in Leichhardt. A correlation analysis will be conducted to assess whether there is a link between the increase of ethnic groups and capital growth in the suburbs. 


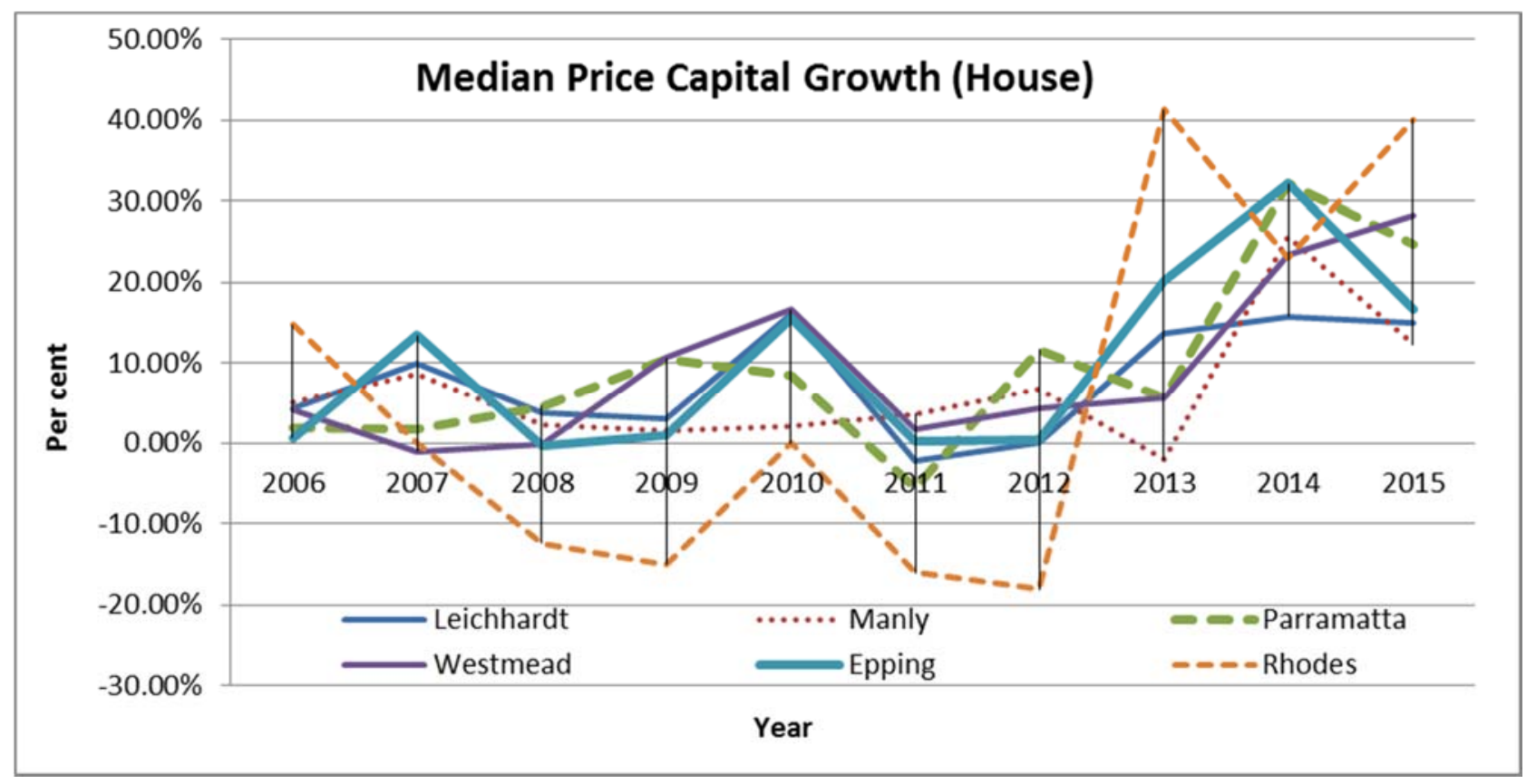

Figure 1: Median House Price Capital Growth (Source: Suburb report, RPData, 2016)

\section{RECENT LITERATURE ON ETHNICITY AND HOUSE PRICES}

Ethnic residential segregation describes the spatial separation of population groups into distinctive residential areas over time (Dunn, et al., 2007). The causes of segregation were identified as neighbourhood disinvestment (Gibson, 2007), real estate discrimination (King and Mieszkowski, 1973), socioeconomic status, spatial assimilation and immigration (Iceland, et al., 2010). Two main theories proposed by Peach (2006) and Boal (1999) were assimilation and multiculturalism on the spatial patterning of ethnic minority immigrant groups alongside that of their host society. Multiculturalism implies that the ethnic minority group members wish to retain their cultural identity and social separateness; whereas assimilation involves gradual removal of economic, cultural and social differences and leads to a reduction and eventual ending of spatial separateness (Johnston, et al., 2007). Relocation, poverty, different quality of education, health issues, behavioural effects, and unequal living standards are the effects of the segregation.

Neighborhood disinvestment is a systematic withdrawal of capital and neglect of public services, such as schools, street and park maintenance, garbage collection and transportation, by the city (Gibson, 2007). By using census data, oral histories, archival documents and newspaper accounts, Gibson analysed residential segregation and neighbourhood disinvestment over a 60-year period from 1940 to 2000 for the black community in the USA. Gibson painted a picture of a cycle of neighbourhood disinvestment followed by gentrification and dislocation of minorities that has made it difficult for African Americans to establish themselves, build equity, and try to break out into suburban neighbourhoods. Minority groups were forced to disinvestment because of absentee landlordism and mortgage redlining and live in areas with overcrowded and volatile environment (Iceland, et al., 2010).

Prejudice and discrimination also shape ethnicity patterns. Discrimination involves members of minority groups being denied access to particular areas (Johnston, et al., 2007). The earlier literature focused on effects of racial discrimination on the housing market and homeownership and mixed results were produced from the studies. King and Mieszkowski (1973) studied over 200 rental units in the New Haven, Connecticut using multiple regression analysis. They found evidences of racial discrimination as blacks and whites paid different amounts for equivalent units. For black female and male-headed households the mark-up relative to white males was 16 percent and 7.5 percent 
respectively. In addition, rents for whites in boundary areas were about 7 percent lower than for black households in these areas. Long and Caudill (1992) and Harris (1999) found that homes in black neighbourhoods are substantially cheaper than comparable homes in white areas; whereas a study by Coates and Vanderhoff (1993) found that homes owned by blacks did not show significantly different appreciation rates than those owned by whites using nationwide sample of AHS for the period of 1974-1983. Despite some declines in discrimination in recent years, Ross and Turner (2005) and Squires, et al. (2006) found that minority neighbourhoods still play central roles in shaping the residential patterns of various ethnic groups in the US.

Disparities in rates at which different racial groups accumulate wealth can be caused by different price-appreciation rates across neighbourhoods of different racial composition. Lower-priced and older homes in the urban centre of Bellingham, Washington experienced higher appreciation than homes more peripheral over the period 1984 to 1994 (Smersh, et al., 1996). Li and Rosenblatt (1997) found that price appreciation in older and less expensive neighbourhoods was higher in three California areas over the period 1990 to 1994. Kim (2000) presented empirical evidence that price appreciation in all-minority neighbourhoods were 3.5 per cent lower than all-white neighbourhoods in Milwaukee for the period 1971 to 1993. Macpherson and Sirmans (2001) examined house price changes and racial/ethnic composition at certain counties in Tampa and Orlando in Florida based on repeat-sales transactions between 1971 and 1997. The variables of African American population, household and economic factors were included in their modelling. They found that the level of and the proportionate change of the African American population had no effects on either Tampa or Oriando areas' prices. However, the level of Hispanic population had a positive effect on Tampa and Orlando housing price. The proportion change of the Hispanic population has a positive relation with Tampa's price and a negative relation with Orlando's price.

Differences in socioeconomic status, spatial assimilation and immigration produce patterns of segregation (Massey, 1985; Iceland, et al., 2010). Lieberson, (1961) suggested that the segregation of ethnic groups declines as their length of residence increases as results of spatial assimilation. Research (Clark, 2007; Fischer, et al., 2004) provided evidences that people of different socioeconomic status are segregated from one another, since minority members may not be able to afford to live the same neighbourhoods as others. Acculturation, i.e., the gradual acquisition of the language, norms and values of the host community (Gordon, 1964), is another mechanism that bring about the dispersion of ethnic groups. The new immigrants like to stay in the community with their language and cultural background. The more the immigrants integrate with the host community, the less their need to live in proximity to their own group, and they tend to move into a qualitatively better neighbourhood when their socioeconomic status has been improved (Bolt, et al. 2008).

The issue of ethnic segregation on neighbourhood house prices has attracted attentions by a number of authors as immigration changes ethnic landscapes ( $\mathrm{Li}, 2014)$. House prices are determined by demand for and supply of houses. Increased house prices for a suburb could be led by increasing numbers of immigrants and changes of ethnic profile. Wong (2013) estimated people's taste for living with own-ethnic-group neighbours in Singapore. She found some evidences of price dispersion across ethnic groups. Recently Li (2014) studied ethnic diversity and neighbourhood house prices in Vancouver Canada. He developed a general equilibrium model using a dataset of housing transactions and neighbourhood socio-economic characteristics. His analysis suggested that neighbourhoods with more homogeneous minority populations command higher prices.

On the other hand, the effects of immigration on house prices are sometimes arguable. Sá (2014) presented evidence of a negative effect on house prices in the UK due to the mobility response of the native population. People who are at the top of the wage distribution move to more affluent areas, being replaced by immigrants with lower education and less well paid jobs. House prices were pushed down because of a negative income effect on housing demand. Similar result was found in Canada by Akbari and Aydede (2012). They applied an econometric analysis based on panel data at census 
division levels from the 1996, 2001 and 2006 population censuses and found a small effect of immigration on prices of privately owned dwellings. The causes include the increasing supply of housing and the native born families moving out from the areas where new immigrants settle down. Results of their research differed from those of Ley and Tutchener (2001), who used simple correlation and factor analysis and suggested that immigration had a strong effect on house prices in Toronto and Vancouver during the period of 1971 to 1996. Their results are also different from those of Saiz (2007) who examined the impact of immigration on housing rents and values in US cities.

Saiz' (2007) empirical analysis used data for US metropolitan areas for the period 1983-1997. Assuming possible simultaneity between immigration and housing rents, he used the instrumental variable method to estimate the models of housing rents and housing price (the instruments include changes in the characteristics of the immigrants' countries of origin, changes in the national levels of immigration, and the distribution of immigrants in earlier periods). The results suggest that there was a positive relationship between immigration and housing rents and values (when inflow of immigration reach a proportion of $1 \%$ of a city's population, a $1 \%$ increase in average housing rents and values can be found) for the period. Jeanty, Partridge \& Irwin (2010) argued that identifying the interaction between migration and housing prices can be complicated by their simultaneous and spatially interdependent relationship. They investigated the relationship by estimating a spatial simultaneous equations model using Michigan census tract-level data. The empirical results suggest that migration can result in an increase in housing prices.

Chen, Guo \& Wu (2011) examined the impacts of rural-urban migration and urbanization on China's housing price using panel data of 29 provinces for the period 1995-2005. They argued that as a result of the unique household registration system, the internal migration in China is divided into two categories: official migration with the transfer of household registration and unofficial migration without the transfer of household registration. The state-supported urban affordable housing is not available for the migrants without the transfer of household registration (who are often referred to as a floating population). They found that urbanization and unofficial migration had different effects on housing price in developed coastal provinces and less-developed inland provinces. In coastal provinces, unofficial migration had no significant effect on housing price while the urbanization level had a negative and statistically significant effect on housing price. In inland provinces, unofficial migration and the urbanization level had a positive and statistically significant effect on housing price. They argued that the different effects of urbanization and unofficial migration on housing price could be explained by different housing prices and different thresholds of obtaining official urban household registration in different regions.

van der Vlist, Czamanski \& Folmer (2011) examined the effect of immigration on housing price in Haifa (Israel). As a result of Israel's fairly loose immigration policy, there was a large inflow of immigrants during the 1990s in Haifa. They estimated an autoregressive distributed model of housing price using panel data of 34 tracts for the period 1989-1999. The spatial spill-over effects and the effect of the government mortgage programme were taken into account in the model. They found a co-integrating relationship between housing price and population. Population had a positive and statistically significant effect on housing price. They also found that over 70 per cent of the gap between the current price and its fundamental value was filled within one year. They argued that because the planning application system was relatively efficient in Israel and there were many national programmes implemented to promote housing construction, housing supply was able to respond quickly to demand shocks.

Gonzalez \& Ortega (2013) examined the impacts of immigration on housing price and housing stock in Spain using panel data of 50 provinces for the period 2000-2010. The change in housing price, or the change in housing stock, could be explained as a function of the change in working-age population, which was largely driven by immigration in the sample year, and a vector of control variables, which included one-year lag of housing price or quantities, the employment-to-population 
ratio and regional dummies. Since housing price and migration decision tend to be simultaneously determined, they used two variables to represent the change in working-age population: an "ethnic networks" variable based on the settlement patterns of earlier immigrants, and a "gateways" variable based on the geographical accessibility of each province with respect to immigrants' countries of origin. They argued that the use of the "gateways" variable is justified by the fact that immigrants from some main source countries have only entered Spain in recent years. They found that the estimates of the coefficients on the change in working-age population obtained when using the instrumental variable approach were almost twice the magnitude of the corresponding OLS estimates. Immigration resulted in a sizable increase in both housing price and the housing stock.

The story seems different in Australia. Unlike literature (Gibson, 2007; Iceland, et al., 2010) in Portland, there is not an evidence of neighbourhood disinvestment in Australia. The discrimination in the US (Ross and Turner, 2005; Squires, et al., 2006) is on a totally different scale to what there is in Australia. In addition, the assumption that minorities (Clark, 2007; Fischer, et al., 2004) are always poor does not apply with the skills program in Australia. The Australian population growth relies heavily on immigration policy. Since the 'White Australia' policy was abandoned in the early 1970s and began to accept large numbers dominated by Asians comprising refugees, family reunions and skilled migration, Australia becomes a multicultural nation with diverse language and cultural backgrounds (ABS, 2015b). People born overseas comprised around 10 per cent of the population after World War II, increased to 28 per cent in 2016 (ABS, 2015b). The top five countries of birth were the UK, New Zealand, China, India and Philippines on 30 June 2015 (Refer to Table 2).

Table 2: Top 10 Countries of Birth Excluding Australia - 30 June 2015

\begin{tabular}{lrr}
\hline & Persons & \\
Country of birth & no. & \% of Australian population \\
\hline United Kingdom & 1207000 & 5.1 \\
New Zealand & 611400 & 2.6 \\
China & 481800 & 2.0 \\
India & 432700 & 1.8 \\
Philippines & 236400 & 1.0 \\
Vietnam & 230200 & 1.0 \\
Italy & 198200 & 0.8 \\
South Africa & 178700 & 0.8 \\
Malaysia & 156500 & 0.7 \\
Germany & 125900 & 0.5 \\
\hline
\end{tabular}

(Note: All population figures presented in this table are rounded. Source: ABS 3412, 2016)

Studies on the ethnic residential segregation have been increasingly attractive. Johnston, et al. (2007) compared the levels of ethnic residential segregation across five English-speaking countries; namely, Australia, Canada, New Zealand, the UK and the US using censuses data from 2000 to 2001, and found that common factors influencing segregation levels in all five countries were the size of the group being considered as a percentage of the urban total and less segregation in Australia and New Zealand than in other three countries. Their findings are confirmed with the research by Poulsen and Johnston (2000) and Burnley, et al. (1997) that Australian cities do not have immigrant ghettos in the same way than American cities. 
The housing price is derived from the supply and demand function under an equilibrium assumption (DiPasquale \& Wheaton, 1994). The determinants of demand for housing can be summarized from the literature review as demographic factors, housing-related elements (Megbolugbe \& Cho, 1993), and macroeconomic variables. The inflow of an immigrant group can lead to local population growth, which in turn can increase the demand for housing in a particular city. The equilibrium housing market may be distorted and housing prices rise given the shortage of housing supply in the shortterm. However, immigration may also be related to native out-migration, or to wages and income decline, which in turn can reduce the demand for housing in a particular city (Sá, 2014). In the longterm, housing prices may adjust to the equilibrium position. Unfortunately, the relationship between ethnicity and house price appreciation is not extensively studied in Australia. One of the few studies was conducted by Bourassa (1994), who compared the housing tenure choices of the Australian-born population with those of 10 major immigrant groups using data from 'Housing and Location Choice Survey' conducted in 1991 in Sydney and Melbourne for the Australian government's National Housing Strategy in Sydney and Melbourne. By controlling differences in the economic and demographic characteristics relevant to the tenure decision, he found that immigrants' tenure choice behaviour is the same as that of Australian-born residents. The recent work done by $\mathrm{Hu}$ and Lee (2016) on cultural distance and housing prices in Australian housing market found a negative relationship between selling price and buyer's cultural distance to the neighbourhood. Home buyers are willing to pay a premium for homes in locations consistent with homebuyers' preference for similar cultures.

\section{METHODOLOGY AND DATA}

Ghetto models have been used to study the ethnic residential segregation, but Poulsen and Johnston (2000) suggested that they are not applicable in Australia. Regression models and graphic analysis (Johnston, et al., 2007) were also commonly employed for the study. The hedonic methodology to regress housing prices on measures of ethnic composition has been commonly applied in the literature either using cross-sectional data (Coulson and Bond, 1990; Bajari \& Kahn, 2005 and Fu, 2005) or panel data (Macpherson and Sirmans, 2001; Clapp et al., 2008 and Saiz \& Wachter, 2011).

The hedonic models (Rosen, 1974) are reduced form statistical models that seek to trace out, at a point in time, the locus of equilibrium transactions prices as a function of the characteristics of the heterogeneous real estate transacted (Geoghegan, 1997). The approach is a widely used technique of analysing the value that is associated to each of the attributes. One of the merits of the hedonic models is the ability to control for housing quality, i.e., combine attributes of demand or supply side observations and capture the weight of each attributes reflecting purchaser preference at a neighbourhood level (Tse, 2002). Rosen (1974) discussed an identification problem using hedonic model since the differential equation defining property prices is nonlinear and it may not be possible to find closed solutions. Thus a great deal of structure must be imposed and partial differential equations must be solved when there is more than one characteristic.

An issue with hedonic models is their potential to produce biased estimation when the functional form is not specified correctly or when all relevant hedonic characteristics are not included, or the parameters have changed over time (Case and Wachter, 2005). Repeat sales method has been used to address such problems. However, McMillen (2008) found that the use of repeat sales suffers from a lack of control of various attributes over time and from a lack of sufficient observations. Some studies adopted hybrid models combining attributes of both repeat sales and hedonic models (Quigley, 1995; Shiller, 1993).

Poulsen, et al. (2001) identified some problems with the using relative measures to create residential area classifications in most studies of ethnic segregation in cities, and suggested the absolute measures to test the theories of spatial separation and a knowledge-based classification method for comparative 
studies. To avoid time series and identification problems, only those properties for which transactions data exists for the census year of 2001 or 2006 or 2011 are considered for Sydney suburbs. Thus the repeat sales method does not apply and changed parameters over time problem is limiting. The equilibrium pricing function in Rosen (1974) can be characterized as the solution to a nonlinear differential equation.

Table 3: Data Profile of the Studied Suburbs

\begin{tabular}{|l|r|r|r|r|r|r|}
\hline \multirow{2}{*}{ Suburbs } & \multicolumn{2}{|c|}{$\mathbf{2 0 0 1}$} & \multicolumn{2}{c|}{$\mathbf{2 0 0 6}$} & \multicolumn{2}{c|}{2011} \\
\cline { 2 - 8 } & Houses & Units & Houses & Units & Houses & Units \\
\hline Epping & 141 & 105 & 129 & 80 & 149 & 220 \\
\hline Leichhardt & 91 & 36 & 126 & 82 & 152 & 80 \\
\hline Manly & 42 & 194 & 37 & 188 & 43 & 334 \\
\hline Parramatta & 59 & 295 & 38 & 213 & 62 & 767 \\
\hline Rhodes & 6 & 3 & 5 & 83 & 11 & 603 \\
\hline Westmead & 25 & 84 & 40 & 123 & 40 & 315 \\
\hline Sub-total & 364 & 717 & 375 & 769 & 457 & 2319 \\
\hline Total & $\mathbf{1 0 8 1}$ & $\mathbf{1 1 4 4}$ & $\mathbf{2 7 7 6}$ \\
\hline
\end{tabular}

The transaction prices were collected from RPData for three census years. The RPData records property address, type of property (house or unit), transaction price, date of transaction, and property structural feature such as number of bedrooms, bathrooms and car spaces. Most of land sizes of houses are recorded; however, most of unit sizes were not recorded, or only total size of unit/apartment block is recorded. Though houses can be measured by per square meter to show characteristic of interest, the unit/apartment price per square meter is difficult to obtain, so the logarithm of property transaction prices are used as a proxy measurement of property size. Table 3 shows the data of houses and units collected for this study.

This paper focuses on the effects of ethnic changes on house prices using a hedonic pricing model (Rosen, 1974). The functional form in a hedonic equation for this study is deriving from a reducedform equation (Case \& Mayer, 1996; Reichert, 1990), which is derived from the supply and demand functions of housing and then inverted under an equilibrium assumption (Equation 1).

$$
P_{t}=f\left(Q_{d}, Q_{s}, t\right) \quad(t=1,2,3, \ldots n)
$$

where $P_{t}$ is the price of housing, i.e., detached houses and units/apartments/flats sold during period $t$ as dependent variable. $Q_{d}$ represents a set of factors that contribute to the aggregate quantity demanded of housing during period $t$ and $Q_{s}$ represents the aggregate quantity of supply during period $t$. Where

$$
\begin{array}{lr}
Q_{d t}=f\left(X_{i}, Y_{i}, t\right) & (t=1,2,3, \ldots n) \\
Q_{s t}=f\left(Z_{i}, t\right) & (t=1,2,3, \ldots n)
\end{array}
$$$$
\text { (2) and }
$$

Real estate is a complicated good with many dimensions that affect housing demands. Differences in selling prices of houses will be dictated by a number of factors, including the quality of the housing structure physical amenities on the property, neighbourhood characteristics or social environment, the accessibility to the central business district, as well as the environmental amenities associated with the property (Geoghegan, et al., 1997). 
A matrix of housing structure and physical amenities on property, represented by $X_{i t}$; a matrix of social environment, denotes by $Y_{i t}$, (Refer to equation 2), and a matrix of supply elements, denoted by $Z_{i t}$ (Refer to Equation 3 ) are included in the estimation.

The first matrix $\left(X_{i t}\right)$ consists of dwelling physical feature, such as number of bedrooms, is included in the estimation. It is assumed that the more bedrooms and bathrooms a house has, the higher the value of the house. As suggested by Kain and Quigley (1970) that physical elements of property are important for households. The numbers of bedroom and bathrooms are converted to logarithm in order to address nonlinear problem.

Since the movement of house prices are affected by local environment as properties are location specific (Macpherson and Sirmans, 2001), the distance of the suburb to Sydney CBD, whether the suburb has rail connection, shopping centre, and proximity to ocean view are also included in the estimation. Those location and accessibility factors affect property values as evidenced by many previous studies such as Giuliano and Agarwal (2010) and Ge \& Lai (2016). Environmental factors like ocean views attract households' interests (Benson, et al., 1998; Fraser and Spencer, 1998). The direct distance measured by kilometre from property suburbs to CBD is used. The kilometre distances are also taken logarithm in the estimation. "Dummy" variables that take the value of ' 1 ' or ' 0 ' are used to represent whether there are or are not rail stations, shopping centres, schools and/or ocean views. The information about rail was sourced from Sydney train website, whereas other variables were collected from google map.

In addition, whether it is a detach house or an apartment/unit are considered in the estimation. A house is usually a single title built on a piece of land that is different from apartments and units, which are strata title properties sharing a piece of land. Thus, houses are usually expected to have higher value than apartments and units/flats because of scarcity of land, when other factors are equal. To reflect this impact, a 'property type' is included in the estimation that is measured by using ' 1 ' and ' 0 ' to represent houses and units/apartments/flats.

The second matrix $\left(Y_{i t}\right)$ includes social environment factors such as crime rate and racial segregation (Fu, 2005) where dwelling location also contributes to dwelling value. Putnam (2000) suggested that local social environment focus on the consequences of social interactions among urban populations that can be estimated by educational performance, crime rate, and other measures of neighbourhood quality of life at the community level. To measure the likely ethnic strength and concentration, especially in the first generation of immigrants, birthplace, parental birthplaces and religious data can be useful. Thus, the proportion of people born in Australia, India, China, the UK, New Zealand and Italy, as well as English proficiency are used to measure the cultural diversities and ethnicity.

Following demographic variables are used to measure the suburb profile and local social environment at the suburb level:

- population

- median age;

- average household size;

- median household weekly income;

- unemployment rate;

- median weekly rent;

- median household monthly loan repayments;

- number of people that has university or technical or equivalent education; and

- number of crimes in the suburb. 
Clapp (1994) tested the effect of economic changes on house prices and found that Property prices are positively correlated with population growth, households' incomes and negatively correlated to unemployment rate.

Crime affects residential stability of neighbourhoods and impacts on housing values. Boggessa, et al., (2013) found that both higher vacancy rates and higher levels of crime in the previous year related to higher rates of housing transactions. A negative impact on property prices is expected when crime rate is high.

Most of variables are sourced from the census data from Australian Bureau of Statistics and converted to logarithms. Some variables are measured by percentage, such as unemployment rate and percentage of ethnic group in the studied suburbs. The crime numbers were sourced from the NSW Bureau of Crime Statistics and Research and taken logarithm for the estimation. Appendix 1 describes the data sets collected and Table 4 defines the variables and their sources included in this study.

The third matrix $\left(Z_{i t}\right)$ consists of housing supply factors. In this study, houses and apartment/units available in each of the studied suburbs are used as proxy of housing supply.

The reduced-form equation can be solved by using a statistical model as indicated in Equation 4 .

$$
\mathrm{P}_{\mathrm{it}}=\beta_{0}+\sum \beta_{\mathrm{i} 1} \mathrm{X}_{\mathrm{it}}+\sum \beta_{\mathrm{i} 2} \mathrm{Y}_{\mathrm{it}}+\sum \beta_{\mathrm{i} 3} \mathrm{Z}_{\mathrm{it}}+\delta_{\mathrm{s}}+\varepsilon
$$

The $\beta_{0}$ is the vector of constant term and $\beta_{\mathrm{i} 1}, \beta_{\mathrm{i} 2}$ and $\beta_{\mathrm{i} 3}$ are matrices of the corresponding parameters. $\delta_{s}$ is a suburb fixed effect, representing physical amenities that serve at least at the suburb level. Some factors that affect dwelling price may not be measurable and $\varepsilon$ represents the error term in the equation.

To overcome the nonlinear issue, the logarithm is used for measuring sale transaction prices and the studied independent variables. Table 4 indicates the measurements and source of the variables used to derive the statistical models. The steps of conducting the research include: a) identifying and collecting physical and social variables that may impact on property prices in accordance with literature; b) analysing the collected data. All collected data was subject to stationarity check, Granger causality test, and examination of correlation of dependent and explanatory variables in order to develop statistical significant models; c) applying the hedonic model using SPSS to generate statistical results; and d) interpreting the results against statistical criteria and analysing the implications.

The developed models are assessed by the coefficient of determination, $\mathrm{R}^{2}$, and coefficient of determination adjusted for degrees of freedom, Adjusted- $\mathrm{R}^{2}$. The developed models are also verified by a model that used the total data sets of all the six studied suburbs. Since the data included three census periods, time variables, are included to reflect the changed economic and other conditions over the time periods. In addition, whether the demands for housing are affected by the changing economic environments of their original countries is considered. Percent Gross Domestic Product of countries of origins for the three census years is also included in the verified model. The verification is to check whether the results of the all data model produce consistent results with the three individually derived models. Next section discusses the results of the derived models. 
Table 4: Definition of Variables and Sources

\begin{tabular}{|c|c|c|c|}
\hline Variables & Measurement & Source & Symbol \\
\hline Sale Transaction Price & Dollar log & RPData & Lprice \\
\hline Bedroom & Number log & RPData & Lbeds \\
\hline Bathroom & Number log & RPData & Lbaths \\
\hline Crime & Number log & BOCSAR $^{\wedge}$ & Lcrime \\
\hline Dwelling type & $1=$ house $; 0=$ unit & RPData & Type \\
\hline Distance to Sydney CBD & Kilometre log & Google & Ldist \\
\hline Rail & $1=$ yes $; 0=$ no & Sydney Train & Rail \\
\hline Shopping centre & $1=$ yes $; 0=$ no & Google & Shop \\
\hline Ocean view & $1=$ yes $; 0=$ no & Google & Ocean \\
\hline Unemployment rate & Per cent & ABS* census & Uemploy \\
\hline Median rent & Weekly \$ log & ABS* census & Lrent \\
\hline Median household income & Weekly \$ log & ABS* census & LHHI \\
\hline Household size & Number $\log$ & ABS* census & Lhsize \\
\hline Median housing loan repayment & Monthly \$ log & ABS* census & Lmortg \\
\hline Population & Number $\log$ & ABS* census & LPOP \\
\hline Birth in Australia & Number $\log$ & ABS* census & BAUS \\
\hline Birth in Overseas & Number $\log$ & ABS* census & Boverseas \\
\hline Birth in India & Per cent & ABS* census, derived & Bindia \\
\hline Birth in Mainland China & Per cent & ABS* census, derived & Bchina \\
\hline Birth in UK & Per cent & ABS* census, derived & BUK \\
\hline Birth in New Zealand & Per cent & ABS* census, derived & $\mathrm{BNZ}$ \\
\hline Birth in Italy & Per cent & ABS* census, derived & Bitaly \\
\hline Birth from all White & Per cent & ABS* census, derived & Bwhite \\
\hline Fully owned house & Number $\log$ & ABS* census & Lfullown \\
\hline Median age & Number $\log$ & ABS* census & Lmage \\
\hline People with mortgage & Number log & ABS* census & Lpmortg \\
\hline Renter & Number $\log$ & ABS* census & Lrented \\
\hline University education & Number $\log$ & ABS* census & Luniversity \\
\hline Technical institution & Number $\log$ & ABS* census & Ltechniq \\
\hline English spoken at home & Number $\log$ & ABS* census & LNEnglishS \\
\hline \multicolumn{4}{|c|}{ *Australian Bureau of Statistics. $\quad$ NSW Bureau of Crime Statistics and Research } \\
\hline
\end{tabular}

\section{FINDINGS AND DISCUSSIONS}

This paper investigates the effects of ethnic changes on dwelling prices in the demographic composition of selected Sydney's suburbs. Six suburbs, i.e., Epping, Leichhardt, Manly, Parramatta, Rhodes and Westmead, which represent the main Australian ethnic groups, have been selected for this pilot study. The results were derived using an hedonic model and reduced form statistical methods (Geoghegan, et al., 1997). 
Before the models were derived, all collected data were subjected to stationarity and Granger causality checks. The correlations of dwelling prices and explanatory variables were also tested as shown in Appendix 2. The test results show that dwelling prices were positively correlated (significant at the 0.01 level) include variables of bedrooms, bathrooms, type of properties, ocean views, household income, rent, age and people born in Australia, UK, NZ Italy; as well as non-English speakers. The results are consistent for all three census years.

Dwelling prices were negatively correlated (significant at the 0.01 level) that are variables such as crime rate, unemployment rate and distance to CBD, rail and shop accessibility. The variables birth in India and China also indicate negative correlations to dwelling prices for all the three studied years. Interestingly, birth overseas, $\mathrm{UK}, \mathrm{NZ}$ and white were negatively correlated to the property prices in 2001 but shown positive correlations in years of 2006 and 2011.

After the data analysis, three statistical significant models were derived based on the collected data sets of the six suburbs for 2001, 2006 and 2011 census (Refer to Table 5). The 2001 model explains the 35.2 per cent variation in prices of the year. The 2006 and 2011 models explain the 47.0 and 53.8 per cent variation in prices.

\section{Effects of physical factors on property prices}

The statistical results show that physical characteristics of dwellings were the major determinants of sale transaction prices identified in all three models. The variables of bedrooms and bathrooms and property type (house or unit/apartment/flat) are correlated positively with property prices. The physical features of dwellings are important factors (See also Kain and Quigley, 1970; Follain and Jimenez, 1985) for home buyers. Given all else being equal, newer, larger homes with more bedrooms, bathrooms, car spaces, as well as better position prospects usually have higher prices. On average, the transaction sale prices of houses are around 7.5 to 8.4 per cent higher than units/apartments/flats.

Table 5: Statistical Significant Models

\begin{tabular}{|c|c|c|c|c|}
\hline Models & 2001 & 2006 & 2011 & All data \\
\hline \multirow[t]{2}{*}{ Constant } & 4.845 & 1.375 & 2.742 & 1.351 \\
\hline & $(67.664)$ & (4.971) & $(11.732)$ & $(13.143)$ \\
\hline \multirow[t]{2}{*}{ Bedrooms } & 0.316 & 0.448 & 0.314 & 0.349 \\
\hline & (5.313) & (8.933) & $(13.867)$ & $(16.564)$ \\
\hline \multirow[t]{2}{*}{ Bathrooms } & 0.282 & 0.314 & 0.722 & 0.293 \\
\hline & $(5.359)$ & $(7.501)$ & $(14.601)$ & $(15.682)$ \\
\hline \multirow[t]{2}{*}{ Proximity to Ocean } & 0.171 & 0.157 & & 0.168 \\
\hline & (7.285) & (8.963) & & $(17.229)$ \\
\hline \multirow[t]{2}{*}{ Property Type } & 0.081 & 0.075 & 0.084 & 0.098 \\
\hline & $(4.27)$ & $(4.814)$ & (9.632) & $(13.064)$ \\
\hline \multirow[t]{2}{*}{ Household Income } & & 1.053 & 0.722 & 1.128 \\
\hline & & $(12.117)$ & $(10.110)$ & $(33.837)$ \\
\hline \multirow[t]{2}{*}{ Birth India } & -0.027 & & -0.006 & -0.003 \\
\hline & $(-6.951)$ & & $(-14.450)$ & $(-8.845)$ \\
\hline \multirow[t]{2}{*}{ Birth UK } & & & & -0.009 \\
\hline & & & & $(-7.269)$ \\
\hline \multirow[t]{2}{*}{ Birth Overseas } & & & & 0.015 \\
\hline & & & & $(6.845)$ \\
\hline Sample Size & 1,081 & 1,144 & 2,776 & 5,001 \\
\hline$R$ Square & 0.355 & 0.472 & 0.538 & 0.505 \\
\hline
\end{tabular}




$\begin{array}{lcccc}\text { Adjusted R Square } & 0.352 & 0.470 & 0.538 & 0.504 \\ \text { F- test } & 118.457 & 203.326 & 646.210 & 636.319 \\ \text { Sig. } & 0.000 & 0.000 & 0.000 & 0.000\end{array}$

\section{Effects of proximity to ocean, shop and rail on property prices}

The variable 'proximity to ocean' contributed greatly to dwelling price movements in the 2001 and 2006 models. Accessibility to natural environment (parks or ocean) improves land values (Benson, et al., 1998). Fraser and Spencer (1998) studied the value of an ocean view for coastal housing subdivision in Western Australia using a modified method of hedonic property amenity valuation. They found positive results. The statistical results suggest that dwelling prices for the suburbs proximate to ocean are expected to be 17.1 per cent higher than the suburbs located inland. This result explains why dwelling prices in Manly, the only beachside suburb of northern Sydney facing Tasman Sea, were higher than other studied suburbs. The variables of 'shop' and 'rail' were not found statistical significant in the derived models. The impacts of shop or rail on property prices are not focused in this paper.

\section{Effects of social and ethnicity factors on property prices}

The statistical results show that household income is one of the main contributors of house prices in 2006 and 2011 models, different from the 2001 model, in which the variable of household income is not statistically significant. The higher the household income, the more their demand for housing. Given the inelasticity of housing supply, dwelling price increases are no surprise. The variables of rent, mortgage and unemployment rate are also not statistically significance in the derived models.

An interesting result is that the effect of ethnic diversity on housing price is negative, particularly in suburbs with large populations born in India. The empirical evidence indicates that price appreciation in the suburbs settled by India-born people were 2.7 per cent lower than the ones by the white neighbourhoods in Sydney in 2001. This result is similar to the findings by Kim (2000) that implies that ethnic groups may make a difference on house value. People prefer to live in a community by the same cultural background (Fu, 2005). Ethnic factors didn't show statistically significance in the 2006 model.

The variable born-in-India population was again found statistically significant in the 2011 model, but the impact on dwelling price is very limited. The results imply that home buyers prefer locations with greater cultural similarity, which supports Hu and Lee (2016). The variables of born-in-UK, born-inItaly, born-in-New Zealand and born-in-Mainland China were not found statistically significant in the developed models. Another cultural variable: English proficiency was also not found statistically significant in the derived models. The reasons may be that income, which is significant, depends very much on English proficiency. Households with higher income may be willing to pay higher prices for locations with similar cultural background (Hu and Lee, 2016). However, for households in the lower income quartile, other factors such as property characteristics, location and schools could be ranked before the ethnicity elements in their consideration of properties.

\section{Model verification}

To verify the developed models, a new model is developed using all collected data, i.e., total of 5,001 data sets, from the three census years. Three additional data sets were included to the model development. First, the total numbers of people born overseas were added. Second, time variables are included in the estimation in order to catch the changes of house prices over time. Third, GDPs percentage changes in the country of origin of ethnic groups, i.e., India, China, Italy, the UK and New Zealand are also included in the model development. This assumes that economic conditions in a country may impact on immigration. More households are able to move to Australia, in particular to 
Sydney, when a country's economy is stronger. Based on Equation 4, a revised statistic model is stated below (Refer to Equation 5).

$$
\mathrm{P}_{\mathrm{it}}=\beta_{0}+\sum \beta_{\mathrm{i} 1} \mathrm{X}_{\mathrm{it}}+\sum \beta_{\mathrm{i} 2} \mathrm{Y}_{\mathrm{it}}+\sum \beta_{\mathrm{i} 3} \mathrm{Z}_{\mathrm{it}}+\sum \beta_{\mathrm{i} 4} \mathrm{~T}_{\mathrm{t}}+\sum \beta_{\mathrm{i} 5} \mathrm{C}_{\mathrm{it}}+\delta_{\mathrm{s}}+\varepsilon
$$

where $T_{t}$ represents the years of 2001, 2006 and 2011 and $C_{i t}$ reflects the economic conditions of the country of origin. The total numbers of people born overseas are included in $Y_{i t}$. The statistics can be found in Appendix 2.

The derived statistically significant model, which is listed in the last column of Table 5, shows consistent results with the other three developed models. The model suggests that property physical factors, i.e., bedrooms and bathrooms are still the main contributors of property prices. Again, proximity to ocean is also statistically significant and the results are consistent with the derived models. It shows that when allowances have been made for all other variables, such as number of rooms and views, houses are still 9.8 per cent more expensive. The attribute of household incomes played a significant role on price appreciation. With regards to the ethnic factors, the model suggests that there was 1.5 per cent increase of property prices with one per cent increase in the number of people born overseas. The empirical evidence indicates that price appreciation in the suburbs settled by India- and UK born people were 0.9 and 0.3 per cent lower than other studied neighbourhoods in Sydney.

The results again demonstrate that house prices are mainly affected by the demand for and supply of houses in the market places (DiPasquale \& Wheaton, 1994). Ethnicity residential segregation is not obvious in Australia. Recently, more and more Asian migrants have been attracted to Australia, while there are positive benefits to Australia of economic linkages to some of the world's largest markets in eastern Asia. According to demographic statistics summarised by CIA (2017), the ethnic groups consist of English (25.9\%), Australian (25.4\%), Irish (7.5\%), Scottish (6.4\%), Italian (3.3\%), German (3.2\%), Chinese (3.1\%), Indian and Greek (1.4\%) and other $17 \%$ including aboriginal $(0.5 \%)$ in 2017. Though the ethnic groups from Asia are relatively small, different from the findings of Johnston, et al (2007), the growing immigrants with different ethnicity have been tolerated by the wider Australian society. The Australian equity and human right policies also contribute to less discrimination, so that minority ethnic group households feel free to purchase dwellings in any state and suburb in Australia. The minimal impacts of ethnicity on house prices thus can be explained. In addition, the results from this study do not support the ideas that different price-appreciation rates cross neighbourhoods are caused by the different racial composition (Smersh, et al. and 1996; Kim, 2000). It might be some unexplained disparities in property market growth rates among the studies suburbs (Refer to Figure 1). However, the property physical attributes and natural environment (such as views) have shown as the main factors that contribute these disparities.

\section{CONCLUSION}

This paper has developed three hedonic models for the purpose of analysing the effects of ethnicity on house prices. Six suburbs that contain large White, Indian or Chinese minority groups have been investigated for the research. The pilot study has provided little evidences of any impact of ethnicity on house price movements, though the variable born-in-India population was found statistically significant in the 2001, 2011 and all-data models. It can be concluded that the impact of ethnic segregation on neighbourhood house prices (Gibson, 2007) is not significant in Sydney. This finding supports Poulsen and Johnston (2000) and Burnley, et al. (1997) who claimed Australian cities do not have immigrant ghettos in the same way that American cities have. The main drivers of house prices are the dwellings' physical characteristics and household income. The locality factor such as proximity to ocean also plays an important role. The ethnic factors do not contribute greatly on the changes of house prices in Sydney. This implies that households with different ethnic groups are not 
isolated. There was no obvious segregation neighbourhood disinvestment (Gibson, 2007) and real estate discrimination (King and Mieszkowski, 1973) found in Australia. The result also demonstrates a successful immigration policy and programs to accommodate immigrants from different ethnic backgrounds in Australia.

The study adds to the growing literature on the ethnicity effects on dwelling prices and is important for understanding whether some of the clusters of ethnic concentration or segregation affect property markets. If there are negative effects, the self-esteem of the minority population could be damaged. If there are positive effects, the higher property prices could lead to affordability issues. Thus, an implication is that policy makers can attract different ethnic groups and encourage communities with different ethnic background when they formulate housing and planning policies. Many policies around the world have been designed to encourage ethnic desegregation in housing markets. In Australia, the Department of Urban Affairs and Planning have developed a new state environmental planning policy that will enshrine 'inclusionary zoning' provisions allowing planning authorities to require the inclusion of affordable housing units in new housing developments. The effects are to create household diversity of socio-economic, structure, age and potentially also ethnicity. Government policies could also be made to influence and attract new immigrants to ethnically mixed suburbs.

\section{ACKNOWLEDGEMENT}

This research is supported by Built Environment Design and Management (BEDM) Research Funding, School of Built Environment, University of Technology Sydney in November 2014.

\section{REFERENCE}

Akbari, A.H. \& Aydede, Y. 2012, Effects of immigration on house prices in Canada, Applied Economics, 44(13):1645-1658.

Australian Bureau of Statistics (ABS) 2015a, Residential Property Price Indexes: Eight Capital Cities, Dec 2015. Accessed at http://www.abs.gov.au/ausstats/abs@.nsf/mf/6416.0 on 19/03/16

Australian Bureau of Statistics (ABS) 2015b, Migration, Australia, 2014-15, Accessed on 19/03/16 at http://www.abs.gov.au/ausstats/abs@.nsf/mf/3412.0/.

Bajari, P. \& Kahn, M.E. 2005, Estimating housing demand with an application to explaining racial segregation in cities, Journal of Business and Economic Statistics, 23: 20-33.

Benson, E.D., Hansen, J.I., Schwartz, A. \& Smersh, G.T. 1998, Pricing residential amenities: the value of a view, Journal of Real Estate Finance and Economics, 16(1):55-73.

Boggessa, L.N.; Greenbaumb, R.T. \& Titac, G.E. 2013, Does crime dirve housing sales? Evidence from Los Angeles, Journal of Crime and Justice, 36(3):299-318.

Boal, F.W. 1999, From undivided cities to undivided cities: As-similation to ethinc cleansing, Housing Studies, 14:585-600.

Bolt, G., Kempen, R.V. \& Ham, M.V. 2008, Minority ethnic groups in the Dutch housing market: spatial segregation, relocation dynamics and housing policy, Urban Studies, 45(7): 1359-1384.

Bourassa, S. 1994, Immigration and housing tenure choice in Australia, Journal of Housing Research, 5(1): $117-136$.

Burnley, O. 1998, Immigrant city, global city? Advantage and disadvantage among communities from Asia in Sydney, The Australian Geographer, 29:49-70. 
Burnley, I., Murphy, P., \& Fagan, B., 1997, Immigration \& Australian Cities. Sydney, Australia: The Federation Press.

Case, K.E. \& Mayer, C.J. 1996, Housing price dynamics within a metropolitan area, Regional Science \& Urban Economics, 26:387-407.

Case, B. \& Wachter, S. 2005, Residential real estate price indices as finanical soundness indicators: methodological issues, BIS paper number 21, 197-211, IMF.

Chen, J., Guo, F. \& Wu, Y. 2011, One decade of urban housing reform in China: urban housing price dynamics and the role of migration and urbanization, 1995-2005, Habitat International, 35(1):1-8.

CIA World Factbook 2017, Australia Demographics Profile 2017, accessed 12 July 2017 on link https://www.cia.gov/library/publications/the-world-factbook/.

Clapp, J.M. 1994, The influence of economic variables on local house price dynamics, Journal of Urban Economics, 36:161-183.

Clapp, J.M., Nanda, A. \& Ross, S.L. 2008, Which school attributes matter? The influence of school district performance and demographic composition on property values, Journal of Urban Economics, 63:451-466.

Clark, W.A.V. 2007, Race, class and place. Urban Affairs Review, 42(3):295-314.

Coates, D. \& Vanderhoff, J. 1993, Race of the homeowner and appreciation of single-family homes in the United States, Journal of Real Estate Finance and Economics, 7: 205-212.

Coulson, N.E. \& Bond, E.W. 1990, A hedonic approach to residnetial succession, The Review of Economic Statistics, 72: 433-444.

Debrezion, G., Pels, E. \& Rietveld, P. 2007, The impact of rail stations on residential and commercial property value: a Meta-analysis, Journal of Real Estate Finance and Economics, 35(2): 161-180.

DiPasquale, D. and Wheaton, W.C. 1994, Housing market dynamics and the future of housing prices, Journal of Urban Economics, 35:1-27.

Dunn, K.M., Kenna, T.E. \& Burnley, I.H. (2007), A holistic approach to studying segregation in Australian cities, SOAC, ISBN 978-0-646-48194-4.

Fischer, C.S., Stockmayer, G. Stiles, J., \& Hout, M. 2004, Geographic levels and social dimensions of Metropolitan segretation, Demography, 41:37-60.

Follain, J.R. and Jimenez, E. (1985) Estimating the demand for housing characteristics: a survey and critique, Regional Science and Urban Economics, 15:77-107.

Fraser, R. \& Spencer, G. 1998, The value of an ocean view: an example of hedonic property amenity valuation, Australian geographical Studies, 36(1):94-98.

$\mathrm{Fu}, \mathrm{S} .2005$, What has been capitalized into property values: human capital, social capital or cultural capital? Working Papers 05-25. Center for Economic Studies, U.S. Census Bureau.

Ge, X.J. \& Lai, P. (2016), Rail accessibility on property value: Zuoying station, $22^{\text {nd }}$ Annual Pacific Rim Real Estate Society Conference, at Sunshine Coast Queensland, Australia on 17 - 20 January 2016. www.prres.net.

Gibson, K.J. 2007, Bleeding Albina: a history of community disinvestment, 1940-2000, Transforming Anthropology, 15(1): 3-25. 
Geoghegan, J., Wainger, L.A. \& Bockstael, N.E. 1997, Analysis spatial landscape indices in a hedonic framework: an ecological economics analysis using GIS, Ecological Economics, 23:251-264.

Gonzalez, L. \& Ortega, F. 2013, Immigration and housing booms: Evidence from spain, Journal of Regional Science, 53(1): 37-59.

Gordon, M. M. (1964) Assimilation in American Life. New York: Oxford University Press.

Guiliano, G. and Agarwal, A. (2010) Public transit as a metropolitan growth strategy, pp. 205-252 in Urban and Regional Policy and its effects, edited by N. Pindus, H. Wial and H. Wolman. Washington DC: Brookings Institution.

Harris, D.R. 1999, Property values drop when blacks move in, because: racial and socioeconomic determinants of neighborhood desirability, American Sociological Review, 64(2): 461-79.

Housing Industry Association (HIA) 2016, accessed on 12 April 2016 at https:/hia.com.au/.

Hu, M.R. \& Lee, A.D. 2016, Melting pot or salad bowl: cultural distance and housing price, Accessed on 20 August 2016 on http://www.cicfconf.org/sites/default/files/paper_102.pdf.

Iceland, J., Goyette, K.A., Neison, K.A. \& Chan, C.W. 2010, Racial and ethnic residential segregation and household structure: a research note, Soc Sci Res. 39(1): 39-47.

Jeanty, P.W., Partridge, M. \& Irwin, E. 2010, Estimation of a spatial simultaneous equation model of population migration and housing price dynamics, Regional Science and Urban Economics, 40(5): 343-52.

Johnston, R. Poulsen, M. and Forrest, J. 2007, The geography of ethnic residential segregation: a comparative study of five countries, Annals of the Association of American Geographers, 97(4):713-738.

Kain, J.F. \& Quigley, J. 1970, Measuring the value of housing quality, Journal of the American Statistical Association 65:532-548.

Kim S. 2000, Race and home price apprecation in urban neighborhoods: evidence from Milwaukee, Wisconsin, The Review of Black Political Economy, 28: 9-30.

King, A.T. \& Mieszkowski, P. 1973, Racial discrimination, segregation, and the price of housing, Journal of Political Economy, 81(3):590-606.

Ley, D. \& Tutchener, J. 2001, Immigration, globalization and house prices in Canada's gateway cities, Housing Studies, 16:199-223.

Li, Q. 2014, Ethnic diversity and neighborhood house prices, Regional Science and Urban Economics, 48: 2138.

Li, Y. \& Rosenblatt, E. 1997, Can urban indicators predict home price appreciation: implications for redlining research, Real Estate Economics, 25(1): 81-104.

Lieberson, S. (1961) The impact of residential segregation on ethnic assimilation, Social Forces, 40:52-57.

Long, J.E. \& Caudill, S.B. 1992, Racial differences in homeownership and housing wealth, 1970-1986, Economic Inquiry, 30(1): 83-100.

Macpherson, D.A. \& Sirmans, G.S. 2001, Neighborhood diversity and house-price appreciation, Journal of Real Estate Finance and Economics, 22(1): 81-97. 
Massey, D. S., 1985, Ethnic residential segregation: a theoretical synthesis and empirical review, Sociology and Social Research, 69: 315-350.

McMillen, D. 2008, Chnages in the distribution of house prices over time: structural characteristics, neighbourhood or coefficients? Journal of Urban Economics, 64:573-589.

Megbolugbe, I.F. and Cho, M. 1993, An empirical analysis of metropolitan housing and mortgage markets. Journal of Housing Research, 4(2):191-210.

New South Wales Bureau of Crime Statistics and Research 2016 on 10/04/2016 at http://www.bocsar.nsw.gov.au/Pages/bocsar_crime_stats/bocsar_crime_stats.aspx.

Peach, C. 2006, The mosaic versus he melting pot: Canada and the U.S.A., Scottish Geographical Journal, 121:3-27.

Phillip, L.J. 1998, Combining quantitative and qualitative approaches to social research in human geography - an impossible mixture? Environment and Planning A, 30:261-276.

Poulsen, M.F. and Johnston, R.J. 2000, The ghetto model and ethnic concentration in Australian cities, Urban Geography, 21(1): 26-44.

Poulsen, M., Johnston, R. \& Forrest, J. 2001, Intraurban ethnic enclaves: introducing a knowledge-based classification method, Envornment and Planning A, 33:2071-2082.

Putnam, R. 2000, Bowling Alone: The collapse and revival of American community, Simon \& Schuster. Quigley, J.M. 1995, A simple hybrid model for estimating real-estate price indexes, Journal of Housing Economics, 4:1-12.

Reicher, A.K. 1990, The impact of interest rates, income and employment upon regional housing prices, Jouranl of Real Estate Finance and Economics, 3:373-391.

Rosen, S. 1974, Hedonic prices and implicit markets: product differentiation in pure competition, Journal of Political Economy, 82: 34-55.

Ross, S.L. \& Turner, M.A. 2005, Housing discrimination in Metropolitan America: Explaining changes between 1989 and 2000, Social Problems, 52(2): 152-80.

RPData, accessed at https://www.corelogic.com.au/, on 20 November 2016.

Sá, F. 2014, Immigration and house prices in the UK, The Economic Journal, 125: 1393-1424.

Saiz, A. 2007, Immigration and housing rents in American cities, Journal of Urban Economics, 61(2): 34571.

Saiz, A. \& Wachter, S. 2011, Immigration and the neighborhood, American Economic Journal Economic Policy, 3:169-188.

Shiller, R.J. 1993, Measuring asset values for cash settlement in derivative markets: hedonic repeated measures indices and perpetural futures, The Journal of Finance, 48:911-931.

Smersh, G.T., Schwarts, A.L. \& Benson, E.D. 1996, Submarket variation in house price appreciation, Paper presented at the American Real Estate Society Meetings.

Squires, G.D. \& Jurbin, C.E. 2006, Privileged places: race residence, and the structure of opportunity, Boulder, CO: Lynne Rienner Publishers, Inc. 
Tse, R.C. 2002, Estimating neighbourhood effects in house prices: towards a new hedonic model approach, Urban Studies, 39(7): 1165-1180.

van der Vlist, A.J., Czamanski, D. \& Folmer, H. 2011, Immigration and urban housing market dynamics: the case of Haifa, The Annals of Regional Science, 47(3): 585-98.

Wong, M. 2013, Esimating ethnic preferences using ethnic housing quotas in Singapore, Review of Economic Studies, 80:1178-1214.

\section{Appendix 1: Data description}

\begin{tabular}{|c|c|c|c|c|c|c|c|c|c|c|c|c|c|c|c|c|c|c|c|c|}
\hline & \multicolumn{5}{|c|}{2001} & \multicolumn{5}{|c|}{2006} & \multicolumn{5}{|c|}{2011} & \multicolumn{5}{|c|}{ Al Data } \\
\hline & $\mathrm{N}$ & Min. & Max. & Mean & SD & $\mathrm{N}$ & Min. & Max. & Mean & SD & $\mathrm{N}$ & Min. & Max. & Mean & SD & $\mathrm{N}$ & Min. & Max. & Mean & SD \\
\hline Lprice & 1081 & 3.57 & 6.97 & 5.5698 & 0.28455 & 1144 & 3.52 & 7.78 & 5.6906 & 0.26909 & 2776 & 3.78 & 7.28 & 5.7495 & 0.21643 & 5001 & 3.52 & 7.78 & 5.6972 & 0.25509 \\
\hline Lbeds & 1081 & 1.00 & 2.08 & 1.3648 & \begin{tabular}{|l|}
0.16711 \\
\end{tabular} & 144 & 1.00 & 1.85 & 1.3630 & 0.16125 & 2776 & 1.00 & 1.90 & 1.3115 & 0.16367 & 5001 & 1.00 & 2.08 & 1.3348 & 0.16589 \\
\hline Lbaths & 1081 & 1.00 & 1.90 & 1. 11155 & 0.16342 & 1144 & 1.00 & 1.70 & 1. 1548 & 0.16642 & 2776 & 1.00 & 1.78 & 1.1488 & 0.16161 & 5001 & 1.00 & 1.90 & 1.1130 & 0.16373 \\
\hline Lcrime & 1081 & 4.15 & 4.84 & 4.4031 & 0.19765 & 1144 & 3.38 & 4.08 & 3.7036 & 0.24327 & 2776 & 3.23 & 4.00 & 3.6139 & 0.28610 & 5001 & 3.23 & 4.84 & 3.8050 & 0.40911 \\
\hline Type & 1081 & 0.00 & 1.00 & 0.3367 & 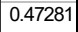 & 1144 & 0.00 & 1.00 & 0.3278 & 0.46962 & 2776 & 0.00 & 1.00 & 0.1646 & 0.37091 & 5001 & 0.00 & 1.00 & 0.2392 & 0.42661 \\
\hline Ldist & 1081 & 0.70 & 1.41 & 1.2363 & 0.20628 & 1144 & 0.70 & 1.41 & 1. 1914 & 0.24225 & 2776 & 0.70 & 1.41 & 1.2463 & 0.18194 & 5001 & 0.70 & 1.41 & 1.2316 & 0.20365 \\
\hline Rail & 1081 & 0.00 & 1.00 & 0.6642 & 0.47249 & 1144 & 0.00 & 1.00 & 0.6215 & 0.48522 & 2776 & 0.00 & 1.00 & 0.7806 & 0.41390 & 5001 & 0.00 & 1.00 & 0.7191 & 0.44951 \\
\hline Shop & 1081 & 0.00 & 1.00 & 0.3358 & 0.47249 & 1144 & 0.00 & 1.00 & 0.2963 & 0.45684 & 2776 & 0.00 & 1.00 & 0.5198 & 0.49970 & 5001 & 0.00 & 1.00 & 0.4289 & 0.49497 \\
\hline Ocean & 1081 & 0.00 & 1.00 & 0.2183 & 0.41329 & 1144 & 0.00 & 1.00 & 0.1967 & 0.39766 & 2776 & 0.00 & 1.00 & 0.1358 & 0.34265 & 5001 & 0.00 & 1.00 & 0.1676 & 0.37352 \\
\hline Uemploy & 1081 & 4.40 & 9.50 & 6.6071 & 2.37138 & 1144 & 3.20 & 8.30 & 5.5762 & 2.27656 & 2776 & 3.70 & 8.20 & 6.7807 & 1.70155 & 5001 & 3.20 & 9.50 & 6.4677 & 2.06077 \\
\hline Lrent & 1081 & 2.35 & 2.74 & 2.4949 & 0.15026 & 1144 & 2.36 & 2.58 & 2.4729 & 0.09023 & 2776 & 2.54 & 2.75 & 2.6357 & 0.08522 & 5001 & 2.35 & 2.75 & 2.5680 & 0.12860 \\
\hline LHHI & 1081 & 2.95 & 3.04 & 2.9923 & 0.03955 & 1144 & 3.01 & 3.20 & 3.1219 & 0.08101 & 2776 & 3.12 & 3.32 & 3.2003 & 0.06874 & 5001 & 2.95 & 3.32 & 3. 1374 & 0.10611 \\
\hline LHsize & 1081 & 0.30 & 0.43 & 0.3706 & 0.04541 & 1144 & 0.32 & 0.45 & 0.3767 & 0.04212 & 2776 & 0.32 & 0.45 & 0.3800 & 0.03622 & 5001 & 0.30 & 0.45 & 0.3772 & 0.03991 \\
\hline Lmortgage & 1081 & 3.04 & 3.38 & 3.1319 & 0.08252 & 144 & 3.20 & 3.38 & 3.2894 & 0.06918 & 2776 & 3.29 & 3.48 & 3.3670 & 0.07116 & 5001 & 3.04 & 3.48 & 3.2984 & 0.11831 \\
\hline LPOP & 1081 & 2.87 & 4.26 & 4. 1871 & 0.14743 & 1144 & 3.22 & 4.28 & 4.0906 & 0.27119 & 2776 & 3.75 & 4.31 & 4. 2291 & 0.20953 & 5001 & 2.87 & 4.31 & 4.1328 & 0.21663 \\
\hline BAUS & 1081 & 0.36 & 0.67 & 0.4926 & 0.10428 & 144 & 0.32 & 0.65 & 0.4754 & 0.11682 & 2776 & 0.27 & 0.65 & 0.4142 & 0.12172 & 5001 & 0.27 & 0.67 & 0.4451 & 0.12215 \\
\hline BOverseas & 1081 & 0.24 & 0.50 & 0.3927 & 0.08615 & 144 & 0.30 & 0.58 & 0.4339 & 0.11057 & 2776 & 0.30 & 5.05 & 1.5560 & 1.86959 & 5001 & 0.24 & 5.05 & 1.0479 & 1.50558 \\
\hline BIndia & 1081 & 0.00 & 6.08 & 3.2097 & 2.51708 & 1144 & 0.32 & 16.27 & 6.3591 & 6.60407 & 2776 & 0.40 & 29.66 & 11.7736 & 10.85201 & 5001 & 0.00 & 29.66 & 8.6839 & 9.47177 \\
\hline BChina & 1081 & 0.01 & 9.35 & 4.5724 & 3.75097 & 1144 & 0.61 & 2.85 & 5.7830 & 4.68488 & 2776 & 0.51 & 25.37 & 12.4324 & 8.66558 & 5001 & 0.01 & 25.37 & 9.2123 & 7.92682 \\
\hline BUK & 1081 & 0.11 & 5.62 & 2.5236 & \begin{tabular}{|l|}
1.67940 \\
\end{tabular} & 144 & 1.68 & 2.55 & 5.0719 & 4.01389 & 2776 & 1.19 & 14.17 & 3.8295 & 4.30975 & 5001 & 0.11 & 14.7 & 3.8314 & 3.91442 \\
\hline BNZ & 1081 & 0.04 & 3.27 & 1.7979 & 1.08321 & 1144 & 1.28 & 4.39 & 2.5712 & 1.08459 & 2776 & 1.11 & 4.15 & 2.0295 & 0.97404 & 5001 & 0.04 & 4.39 & 2.1033 & 1.05933 \\
\hline Bltaly & 1081 & 0.00 & 5.42 & 0.9405 & 1.65003 & 1144 & 0.27 & 3.75 & 1.0371 & 1.29055 & 2776 & 0.25 & 3.75 & 0.6198 & 0.94962 & 5001 & 0.00 & 5.42 & 0.7846 & 1.22647 \\
\hline Bwhite & 1081 & 0.16 & 14.31 & 5.2620 & 3.92816 & 1144 & 4.13 & 17.36 & 8.6801 & 5.37970 & 2776 & 3.09 & 18.84 & 6.4788 & 5.57687 & 5001 & 0.16 & 18.84 & 6.7193 & 5.34613 \\
\hline Lfowned & 1081 & 2.06 & 3.52 & 3.2244 & 0.22146 & 1144 & 2.06 & 3.44 & 3.0153 & 0.35058 & 2776 & 2.46 & 3.45 & 2.9278 & 0.31554 & 5001 & 2.06 & 3.52 & 3.0119 & 0.32808 \\
\hline Lmage & 1081 & 1.51 & 1.59 & 1.5304 & 0.02116 & 1144 & 1.48 & 1.57 & 1.5272 & 0.03184 & 2776 & 1.45 & 1.58 & 1.5017 & 0.04644 & 5001 & 1.45 & 1.59 & 1.5137 & 0.04132 \\
\hline Lpmortgage & 1081 & 1.75 & 3.12 & 2.9420 & \begin{tabular}{|l|}
0.18941 \\
\end{tabular} & 1144 & 2.28 & 3.26 & 3.0425 & 0.26147 & 2776 & 2.80 & 3.32 & 3.1112 & 0.18521 & 5001 & 1.75 & 3.32 & 3.0589 & 0.21668 \\
\hline Lrented & 1081 & 1.84 & 3.60 & 3.4144 & 0.20855 & 1144 & 2.43 & 3.64 & 3.3300 & 0.29530 & 2776 & 3.08 & 3.64 & 3.4109 & 0.20920 & 5001 & 1.84 & 3.64 & 3.3932 & 0.23410 \\
\hline Lnuniversity & 1081 & 1.58 & 3.23 & 3.0193 & 0.19507 & 1144 & 2.15 & 3.26 & 2.9870 & 0.29704 & 2776 & 2.88 & 3.30 & 3.0796 & 0.15559 & 5001 & 1.58 & 3.30 & 3.0454 & 0.20832 \\
\hline LNT ech & 1081 & 1.28 & 2.91 & 2.7223 & 0.19095 & 1144 & 1.64 & 2.86 & 2.5320 & 0.29581 & 2776 & 2.22 & 2.77 & 2.5445 & 0.20122 & 5001 & 1.28 & 2.91 & 2.5801 & 0.23655 \\
\hline LNEspeaker & 1081 & 2.73 & 4.08 & 3.9181 & 0.17593 & 1144 & 2.93 & 4.04 & 3.8100 & 0.31063 & 2776 & 3.17 & 4.06 & 3.6865 & 0.31812 & 5001 & 2.73 & 4.08 & 3.7648 & 0.30638 \\
\hline Time01 & & & & & & & & & & & & & & & & 5001 & 0.00 & 1.00 & 0.2162 & 0.41166 \\
\hline Time06 & & & & & & & & & & & & & & & & 5001 & 0.00 & 1.00 & 0.2288 & 0.42007 \\
\hline Time11 & & & & & & & & & & & & & & & & 5001 & 0.00 & 1.00 & 0.5551 & 0.49701 \\
\hline GdpChina & & & & & & & & & & & & & & & & 5001 & 8.34 & 12.72 & 10.0056 & 1.55138 \\
\hline Gdpltaly & & & & & & & & & & & & & & & & 5001 & 0.58 & 2.01 & 1. 1624 & 0.65865 \\
\hline GdpIndia & & & & & & & & & & & & & & & & 5001 & 4.82 & 9.26 & 6.8466 & 1.49856 \\
\hline GdpNZ & & & & & & & & & & & & & & & & 5001 & 2.48 & 3.44 & 2.7859 & 0.38669 \\
\hline GdpUK & & & & & & & & & & & & & & & & 5001 & 1.51 & 2.73 & 1.9994 & 0.55289 \\
\hline
\end{tabular}


Appendix 2: Correlations

\begin{tabular}{|c|c|c|c|c|c|c|c|c|}
\hline \multirow[t]{2}{*}{ Variables } & \multicolumn{2}{|c|}{ Lpriceall } & \multicolumn{2}{|c|}{ Lprice 01} & \multicolumn{2}{|c|}{ Lprice 06} & \multicolumn{2}{|c|}{ Lprice11 } \\
\hline & $\begin{array}{c}\text { Pearson } \\
\text { Correlati } \\
\text { on }\end{array}$ & $\begin{array}{l}\text { Sig. (2- } \\
\text { tailed) }\end{array}$ & \begin{tabular}{|c|} 
Pearson \\
Correlatio \\
$n$
\end{tabular} & $\begin{array}{l}\text { Sig. (2- } \\
\text { tailed) }\end{array}$ & $\begin{array}{c}\text { Pearson } \\
\text { Correlatio } \\
n\end{array}$ & $\begin{array}{l}\text { Sig. (2- } \\
\text { tailed) }\end{array}$ & \begin{tabular}{c|} 
Pearson \\
Correlation
\end{tabular} & $\begin{array}{l}\text { Sig. (2- } \\
\text { tailed) }\end{array}$ \\
\hline Lbeds & $.365^{* *}$ & 0.000 & $.346^{* *}$ & 0.000 & $.434^{* *}$ & 0.000 & $.464^{* *}$ & 0.000 \\
\hline Lbaths & $.358^{* *}$ & 0.000 & $.345^{* *}$ & 0.000 & $.402^{* *}$ & 0.000 & $.333^{* *}$ & 0.000 \\
\hline Lcrime & $-.463^{* *}$ & 0.000 & $-.198^{\star *}$ & 0.000 & $-.468^{* *}$ & 0.000 & $-.496^{\star \star}$ & 0.000 \\
\hline Type & $.273^{* *}$ & 0.000 & $291^{* *}$ & 0.000 & $311^{* *}$ & 0.000 & $.389^{* *}$ & 0.000 \\
\hline Ldist & $-.254^{\star *}$ & 0.000 & $-.225^{* *}$ & 0.000 & $-179^{* *}$ & 0.000 & $-.368^{\star *}$ & 0.000 \\
\hline Rail & $-.318^{* *}$ & 0.000 & $-.366^{* *}$ & 0.000 & $-.329^{* *}$ & 0.000 & $-.391^{* *}$ & 0.000 \\
\hline Shop & $-.242^{* *}$ & 0.000 & $-.367^{* *}$ & 0.000 & $-.306^{* *}$ & 0.000 & $-.279^{* *}$ & 0.000 \\
\hline Ocean & $.295^{* *}$ & 0.000 & $.346^{* *}$ & 0.000 & $.353^{* *}$ & 0.000 & $.317^{* *}$ & 0.000 \\
\hline UEM & $-.412^{* *}$ & 0.000 & $-.449^{* *}$ & 0.000 & $-.442^{* *}$ & 0.000 & $-.468^{* *}$ & 0.000 \\
\hline Lrent & $.435^{* *}$ & 0.000 & $.313^{* *}$ & 0.000 & $.476^{* *}$ & 0.000 & $.452^{* *}$ & 0.000 \\
\hline LHHI & $.510^{* *}$ & 0.000 & $.458^{* *}$ & 0.000 & $.488^{* *}$ & 0.000 & $.535^{* *}$ & 0.000 \\
\hline LHsize & $-.155^{* *}$ & 0.000 & $-.217^{* *}$ & 0.000 & $-.152^{* *}$ & 0.000 & $-.193^{* *}$ & 0.000 \\
\hline Lmortgage & $.510^{* *}$ & 0.000 & $.460^{* *}$ & 0.000 & $.461^{* *}$ & 0.000 & $.527^{* *}$ & 0.000 \\
\hline LPOP & $-.116^{* *}$ & 0.000 & -0.040 & 0.189 & -0.034 & 0.250 & $-.157^{* *}$ & 0.000 \\
\hline BAUS & $.331^{* *}$ & 0.000 & $.370^{* *}$ & 0.000 & $383^{* *}$ & 0.000 & $.509^{* t}$ & 0.000 \\
\hline BOveaseas & $.112^{* *}$ & 0.000 & $-.452^{* *}$ & 0.000 & $-.441^{* *}$ & 0.000 & $.065^{* *}$ & 0.001 \\
\hline Blndia & $-.298^{* *}$ & 0.000 & $-.464^{* *}$ & 0.000 & $-.471^{* *}$ & 0.000 & $-.538^{* *}$ & 0.000 \\
\hline BChina & $-.065^{* *}$ & 0.000 & $-.423^{* *}$ & 0.000 & $-.378^{* *}$ & 0.000 & $-.147^{* *}$ & 0.000 \\
\hline BUK & $.348^{* *}$ & 0.000 & $-.075^{*}$ & 0.014 & $.426^{* *}$ & 0.000 & $.417^{* *}$ & 0.000 \\
\hline BNZ & $.144^{* *}$ & 0.000 & $-.352^{* *}$ & 0.000 & $258^{* *}$ & 0.000 & $.338^{* *}$ & 0.000 \\
\hline Bltaly & $.099^{* *}$ & 0.000 & $.068^{*}$ & 0.026 & $.080^{* *}$ & 0.007 & $.237^{* *}$ & 0.000 \\
\hline Bwhite & $.306^{* *}$ & 0.000 & $-.101^{* *}$ & 0.001 & $.389^{* *}$ & 0.000 & $.422^{* *}$ & 0.000 \\
\hline LfOwned & $.072^{* *}$ & 0.000 & $.243^{* *}$ & 0.000 & $.192^{* *}$ & 0.000 & $182^{* *}$ & 0.000 \\
\hline Lmage & $.217^{* *}$ & 0.000 & $392^{* *}$ & 0.000 & $.410^{* *}$ & 0.000 & $325^{* *}$ & 0.000 \\
\hline LPmortgage & $.082^{* *}$ & 0.000 & $.080^{* *}$ & 0.009 & -0.007 & 0.826 & $-.048^{*}$ & 0.011 \\
\hline Lrented & $-.198^{* *}$ & 0.000 & $-.146^{* *}$ & 0.000 & $-.147^{* *}$ & 0.000 & $-.291^{* *}$ & 0.000 \\
\hline Lnuniversity & $-.090^{* *}$ & 0.000 & -0.038 & 0.212 & $-.102^{* *}$ & 0.001 & $-.210^{* *}$ & 0.000 \\
\hline LNTech & $-.292^{* *}$ & 0.000 & $-.446^{* *}$ & 0.000 & $-.174^{* *}$ & 0.000 & $-.283^{* *}$ & 0.000 \\
\hline LNESpeaker & $.097^{* *}$ & 0.000 & $.315^{* *}$ & 0.000 & $205^{* *}$ & 0.000 & $.179^{* *}$ & 0.000 \\
\hline Time01 & $-.262^{* *}$ & 0.000 & & & & & & \\
\hline Time06 & -0.014 & 0.316 & & & & & & \\
\hline Time11 & $.229^{* *}$ & 0.000 & & & & & & \\
\hline GdpChina & $.071^{* *}$ & 0.000 & & & & & & \\
\hline Gdpltaly & $-.209^{* *}$ & 0.000 & & & & & & \\
\hline Gdplndia & $.120^{* *}$ & 0.000 & & & & & & \\
\hline GdpNZ & $-.275^{* *}$ & 0.000 & & & & & & \\
\hline GdpUK & $-.248^{* *}$ & 0.000 & & & & & & \\
\hline${ }^{* *}$. Correlation & nificant at & e 0.01 leve & tailed). & & & & & \\
\hline
\end{tabular}

